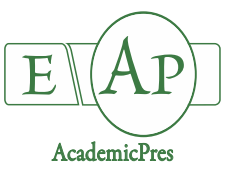

Ergin N and Kaya MD (2020)

Notulae Botanicae Horti Agrobotanici Cluj-Napoca 48(3):1465-1472

DOI: $10.15835 /$ nbha48311826

Research Article

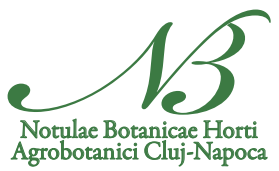

\title{
The effectiveness of herbicidal desiccants and application times on seed yield and earliness of soybean
}

\author{
Nurgül ERGİN ${ }^{1 *}$, Mehmet D. KAYA ${ }^{2}$ 11230 Center, Bilecik, Turkey; nurgulergin180@gmail.com (*corresponding author)
${ }^{2}$ Eskişsehir Osmangazi University, Faculty of Agriculture, Department of Field Crops, Ali Numan Kıraç Campus, Ziraat Street, Kütahya Road, 26160 Odunpazarı, Eskişehir, Turkey; demirkaya@ogu.edu.tr \\ ${ }^{1}$ Bilecik Şeyh Edebali University, Faculty of Agriculture and Natural Science, Department of Field Crop, D Block, Gülümbe Campus,
}

\begin{abstract}
Two herbicidal desiccants and five application times at different reproductive stages of soybean were investigated for earliness without significant reduction in seed yield and quality. Glyphosate and diquat were applied to soybean cv. 'Arısoy' (maturity group III) at growth stages of $\mathrm{R}_{5}, \mathrm{R}_{6}, \mathrm{R}_{7}$ and $\mathrm{R}_{8}$. Full maturity (FM) and uprooted plants at each growth stage were also used as a control. Plant height, first pod height, pod number per plant, seed weight per plant, thousand seed weight, seed yield and oil ratio were investigated. The results showed that plant height was not affected by desiccants and application times. Lower seed weight per plant, thousand seed weight, seed yield, and oil ratio were obtained from earlier reproductive stages, especially at $R_{5}$, and $\mathrm{R}_{6}$, but glyphosate produced higher seed yield and oil content than diquat. Both desiccants considerably reduced seed yield when applied at $R_{5}$ and $R_{6}$. Mean seed yield enhanced from 1,364 to 3,036 kg ha-1 in first year and from 1,097 to $2,804 \mathrm{~kg} \mathrm{ha}^{-1}$ in second year as the growth stages extended from $\mathrm{R}_{5}$ to $\mathrm{R}_{8}$. Diquat was more effective desiccant for accelerating soybean harvest than glyphosate, while higher seed yield was obtained from glyphosate spraying at $R_{5}$ and $R_{6}$ stages. Increased seed yield was observed in diquat application when the soybean growth stages were delayed from $R_{5}$ to $R_{8}$. It was concluded that glyphosate should be applied at $R_{7}$ in soybean for earliness with 7-10 days in harvest and no desiccant should be suggested before $\mathrm{R}_{7}$ stages.
\end{abstract}

Keywords: application stage; defoliation; Glycine max L., growth stage; seed yield

\section{Introduction}

Turkey imports soybean seeds, cake, raw and refined oil every year and the import value has reached up to 2 billion dollars nowadays (Anonymus, 2019). Soybean is an economically important for our poultry industry due to rich protein and oil contents of the seeds. The production of soybean is strictly supported by the Turkish government to meet the demand of soybean products (Kolsarıc1 et al., 2015), while its cultivation has been limited into Mediterranean region, subtropical climatic zone of Turkey (Kulan et al., 2017). For these reasons, the sowing area of soybean must be expanded to increase the production of soybean under different regions with temperate ecology. Central Anatolian region, characterized as continental climate with snowy and cold winter, and dry and temperate summer, has a potential to meet the demand of soybean. Torunlar and Nazlican (2018) estimated that approximately 9.5 million ha are suitable for soybean production in this region. 
However, its cultivation is inhibited by two main problems dealing with low temperature in spring months, and rainy and cold weather conditions in autumn, which lead to limiting vegetation period from planting to harvest; consequently, soybean growing period must be shortened or accelerated by several cultivation methods.

One of the most promising methods for shortening growing period is the use of harvest aid chemicals, which are referred as desiccants and defoliants. They have successfully been applied for earlier harvest than normal (Pereira et al., 2015). Among these chemicals, paraquat, diquat and glyphosate have been commonly used for desiccation in soybean (Azlin and McWhorter, 1981; Zagonel, 2005; Boudreaux and Griffin, 2011) in order to accelerate maturity. Therefore, this study aimed to investigate the possibilities of herbicidal desiccants such as diquat and glyphosate, extensively used as weed killer, for shortening the harvest period without causing a significant decrease in seed yield and quality of soybean.

\section{Materials and Methods}

\section{Description of the study site}

Field experiments were established in 2016 and 2018, at the experimental field of Department of Field Crops, Eskişehir Osmangazi University, Eskişehir-Turkey. Soybean cultivar 'Arısoy' with maturity group III was used and experienced for growing performance under Eskişehir conditions by Kulan et al. (2017). The soil of the experimental areas was loamy with $0.88-1.76 \%$ organic matter and slightly alkaline $(\mathrm{pH}=7.6-8.2)$. The seeds were planted on April 29, 2016 and April 17,2018. The climate was characterized as continental climate by warm and dry in summer months, cold and snowy during winter. In the experimental years, mean temperatures during the growing period were $17.5^{\circ} \mathrm{C}$ and $18.8^{\circ} \mathrm{C}$, respectively. Total rainfall was $170 \mathrm{~mm}$ in 2016 and $228 \mathrm{~mm}$ in 2018. Because rainfall was insufficient to supply soybean water requirement, springer irrigation was applied when the plants needed.

\section{Experimental procedures}

The planting was done manually with plant density of $70 \times 3 \mathrm{~cm}$. Each plot was consisted of four rows and the plot size was $2.8 \mathrm{~m}$ by $4 \mathrm{~m}$ with dimension of $11.2 \mathrm{~m}^{2}$. The desiccant treatments were arranged according to soybean growth stages. They were applied when the soybean plants reached to $R_{5}, R_{6}, R_{7}$ and $R_{8}$ stages described as following. No desiccant spraying was performed in full maturity and the plants were harvested manually.

$\mathrm{R}_{5}$ : Visible seed in pod of the four uppermost nodes on the main stem

$\mathrm{R}_{6}$ : Beans touching inside pods of the four uppermost nodes on the main stem

$\mathrm{R}_{7}$ : Pod mature in colour anywhere on plant

$\mathrm{R}_{8}$ : Approximately $50 \%$ of the pods mature in colour and containing mature seed

Full maturation: $95 \%$ of pods reached to maturation and seed moisture below $13 \%$

The desiccants of diquat at $6,000 \mathrm{~mL} \mathrm{ha}^{-1}$ and glyphosate at $8,000 \mathrm{~mL} \mathrm{ha}^{-1}$ with $300 \mathrm{~L}$ water per hectare were pulverized onto the plants in each growth stage by backpack sprayer. Also, naturally full maturity (FM) was used for comparing the investigated parameters to the desiccant applications. Uprooted and dried plants on soil surface at each growth stage were evaluated as control (C).

In both years, the plants were fertilized with $30 \mathrm{~kg} \mathrm{ha}^{-1}$ nitrogen and $60 \mathrm{~kg} \mathrm{ha}^{-1} \mathrm{P}_{2} \mathrm{O}_{5}$ before sowing. Preemergence herbicide (Linuron $450 \mathrm{~g} \mathrm{~L}^{-1}$ ) was applied to kill weeds after sowing and hand hoeing was performed at 30 days after emergence along with nitrogen of $200 \mathrm{~kg} \mathrm{ha}^{-1}$ as ammonium sulphate. Additional nitrogen dose (urea) of $200 \mathrm{~kg} \mathrm{ha}^{-1}$ was broadcasted prior to first irrigation. At maturity, ten plants were randomly selected from each plot and were used to determine yield and yield components. The oil percentage was determined by Soxhelet extraction (Gerhardt Soxtherm 414, Germany) method using n-Hexane as a solvent. The experiment was designed by randomized complete blocks with four replicates and comparison of the means was done by Duncan’s Multiple Range Test using MSTAT-C (Michigan State University v. 2.10) software. 


\section{Results and Discussion}

The results of analysis of variance with significance levels of the main effect of the years, desiccants and applications times, two- and three-way interactions on the investigated parameters were shown in Table 1 . The results from each experimental year were also given separately in Table 2 and Table 3 . A significant difference between the experimental years was determined in all the parameters except for oil ratio. The longer plant height and first pod height were obtained in the second year, while higher seed weight, pod number and seed yield were recorded in the first year. Desiccants clearly affected the yield parameters of soybean and glyphosate was superior to diquat. The highest one thousand seed weight and seed yield were detected in glyphosate application without any changes in oil ratio. Application time significantly influenced the parameters and delayed application times promoted seed yield. The highest oil ratio was measured in $\mathrm{R}_{6}$ with $21.1 \%$.

Table 1. Main effects of year, desiccant and application time on seed yield and yield components of soybean

\begin{tabular}{|c|c|c|c|c|c|c|c|}
\hline Factors & $\begin{array}{l}\text { Plant } \\
\text { height } \\
(\mathrm{cm})\end{array}$ & $\begin{array}{c}\text { First pod } \\
\text { height } \\
(\mathrm{cm})\end{array}$ & $\begin{array}{c}\text { Pod } \\
\text { number per } \\
\text { plant }\end{array}$ & $\begin{array}{l}\text { Seed weight } \\
\left.\text { (g plant }^{-1}\right)\end{array}$ & $\begin{array}{l}\text { Thousand } \\
\text { seed weight } \\
\text { (g) }\end{array}$ & $\begin{array}{l}\text { Seed yield } \\
\left(\mathrm{kg} \mathrm{ha}^{-1}\right)\end{array}$ & $\begin{array}{c}\text { Oil ratio } \\
(\%)\end{array}$ \\
\hline \multicolumn{8}{|c|}{ Years } \\
\hline $1^{\text {st }}$ Year & $103.8 \mathrm{~b}$ & $13.5 \mathrm{~b}$ & $129.5 \mathrm{a}$ & $38.5 \mathrm{a}$ & $143.6 \mathrm{a}$ & 2,441 a & 20.3 \\
\hline $2^{\text {nd }}$ Year & $114.1 \mathrm{a}$ & $21.1 \mathrm{a}$ & $51.4 \mathrm{~b}$ & $12.5 \mathrm{~b}$ & $103.7 \mathrm{~b}$ & $2,228 \mathrm{~b}$ & 20.2 \\
\hline \multicolumn{8}{|c|}{ Desiccant } \\
\hline Control & 111.6 & $17.2 \mathrm{~b}$ & $97.7 \mathrm{a}$ & 26.9 & 119.8 & $2,222 \mathrm{~b}$ & 20.1 \\
\hline Diquat & 104.1 & $16.5 \mathrm{~b}$ & $89.8 \mathrm{~b}$ & 25.7 & 123.9 & $2,237 \mathrm{~b}$ & 20.6 \\
\hline Glyphosate & 111.1 & $18.2 \mathrm{a}$ & $83.8 \mathrm{~b}$ & 23.9 & 127.2 & $2,544 \mathrm{a}$ & 20.1 \\
\hline \multicolumn{8}{|c|}{ Application time } \\
\hline $\mathrm{R}_{5}$ & 107.0 & $16.8 \mathrm{bc}$ & $85.6 \mathrm{~b}$ & $11.7 \mathrm{e}$ & $88.6 \mathrm{c}$ & $1,231 \mathrm{~d}$ & $19.0 \mathrm{c}$ \\
\hline $\mathrm{R}_{6}$ & 107.9 & $19.8 \mathrm{a}$ & $86.3 \mathrm{~b}$ & $20.1 \mathrm{~d}$ & $117.4 \mathrm{~b}$ & $2,000 \mathrm{c}$ & $21.1 \mathrm{a}$ \\
\hline $\mathrm{R}_{7}$ & 109.2 & $16.1 \mathrm{c}$ & $100.8 \mathrm{a}$ & $36.2 \mathrm{a}$ & $137.4 \mathrm{a}$ & $2,651 \mathrm{~b}$ & $20.9 \mathrm{ab}$ \\
\hline $\mathrm{R}_{8}$ & 113.1 & $17.5 \mathrm{~b}$ & $89.6 \mathrm{~b}$ & $32.8 \mathrm{~b}$ & $137.6 \mathrm{a}$ & $2,869 \mathrm{a}$ & $20.2 \mathrm{~b}$ \\
\hline FM & 107.5 & $16.1 \mathrm{c}$ & $89.8 \mathrm{~b}$ & $26.8 \mathrm{c}$ & $137.2 \mathrm{a}$ & $2,921 \mathrm{a}$ & $20.2 \mathrm{~b}$ \\
\hline \multicolumn{8}{|c|}{ Analysis of Variance (ANOVA) } \\
\hline Year $(Y)$ & * & ** & ** & $* *$ & ** & * & ns \\
\hline Desiccant (D) & ns & ** & ** & ns & ns & * & ns \\
\hline $\begin{array}{c}\text { Application } \\
\text { time (AT) }\end{array}$ & ns & ** & ** & ** & $* *$ & $* *$ & $* *$ \\
\hline $\mathrm{Y} \times \mathrm{D}$ & ns & ** & ** & $\mathrm{ns}$ & ns & ns & $\mathrm{ns}$ \\
\hline $\mathrm{Y} \times \mathrm{AT}$ & ns & ** & ** & ** & ** & ** & * \\
\hline $\mathrm{D} \times \mathrm{AT}$ & ns & ** & $* *$ & ** & $* *$ & $* *$ & ns \\
\hline $\mathrm{Y} \times \mathrm{D} \times \mathrm{AT}$ & ns & $* *$ & $* *$ & ** & ns & $* *$ & $*$ \\
\hline
\end{tabular}

${ }^{*},{ }^{* *}$ show significance level at $\mathrm{p}<0.05$ and $\mathrm{p}<0.01$ respectively; ns: non-significant; $\uparrow:$ Means followed by same letter $(\mathrm{s})$ are not significant. 
Table 2. Changes in plant height, first pod height, pod number, seed weight of soybean affected by desiccants and application times

\begin{tabular}{|c|c|c|c|c|c|c|c|c|}
\hline & \multicolumn{4}{|c|}{$1^{\text {st }}$ year } & \multicolumn{4}{|c|}{$2^{\text {nd }}$ year } \\
\hline Stage & Uprooted & Diquat & Glyphos. & Mean & Uprooted & Diquat & Glyphos. & Mean \\
\hline & \multicolumn{8}{|c|}{ Plant height $(\mathrm{cm})$} \\
\hline $\mathrm{R}_{5}$ & 109 & 103 & 102 & 105 & 115 & 96 & 116 & 109 \\
\hline $\mathrm{R}_{6}$ & 106 & 96 & 102 & 102 & 110 & 107 & 125 & 114 \\
\hline $\mathrm{R}_{7}$ & 107 & 95 & 104 & 102 & 110 & 116 & 122 & 116 \\
\hline $\mathrm{R}_{8}$ & 115 & 104 & 105 & 108 & 119 & 118 & 118 & 118 \\
\hline FM & 111 & 93 & 103 & 102 & 113 & 113 & 113 & 113 \\
\hline \multirow[t]{2}{*}{ Mean } & 110 & 98 & 103 & & 113 & 110 & 119 & \\
\hline & \multicolumn{8}{|c|}{ First pod height $(\mathrm{cm})$} \\
\hline $\mathrm{R}_{5}$ & $15.5 \mathrm{~b}$ & $14.3 \mathrm{bc}$ & $13.7 \mathrm{c}$ & $14.5 \mathrm{~b}$ & $14.5 \mathrm{~d}$ & $20.4 \mathrm{bc}$ & $22.8 \mathrm{bc}^{*}$ & $19.2 \mathrm{~b}$ \\
\hline $\mathrm{R}_{6}$ & $19.5 \mathrm{a}$ & $13.8 \mathrm{bc}$ & $14.5 \mathrm{bc}$ & $15.9 \mathrm{a}$ & $23.6 \mathrm{ab}$ & $21.5 \mathrm{bc}$ & $26.0 \mathrm{a}$ & $23.7 \mathrm{a}$ \\
\hline $\mathrm{R}_{7}$ & $11.8 \mathrm{~d}-\mathrm{g}$ & $11.2 \mathrm{fg}$ & $13.5 \mathrm{~cd}$ & $12.2 \mathrm{c}$ & $19.4 \mathrm{c}$ & $20.4 \mathrm{bc}$ & $20.3 \mathrm{bc}$ & $20.1 \mathrm{~b}$ \\
\hline $\mathrm{R}_{8}$ & $14.2 \mathrm{bc}$ & $11.6 \mathrm{efg}$ & $11.5 \mathrm{efg}$ & $12.4 \mathrm{c}$ & $20.9 \mathrm{bc}$ & $20.8 \mathrm{c}$ & $26.4 \mathrm{a}$ & $22.7 \mathrm{a}$ \\
\hline FM & $13.2 \mathrm{cde}$ & $11.1 \mathrm{~g}$ & $13.0 \mathrm{c}-\mathrm{f}$ & $12.4 \mathrm{c}$ & $19.9 \mathrm{c}$ & $19.6 \mathrm{~b} \mathrm{c}$ & $19.6 \mathrm{bc}$ & $19.7 \mathrm{~b}$ \\
\hline \multirow[t]{2}{*}{ Mean } & $14.8 \mathrm{a}$ & $12.4 \mathrm{~b}$ & $13.2 \mathrm{~b}$ & & $19.7 \mathrm{~b}$ & $20.5 \mathrm{~b}$ & $23.0 \mathrm{a}$ & \\
\hline & \multicolumn{8}{|c|}{ Pod number per plant (number plant $\left.{ }^{-1}\right)$} \\
\hline $\mathrm{R}_{5}$ & $127 \mathrm{bc}$ & $123 \mathrm{c}$ & $110 \mathrm{c}$ & $120 \mathrm{~b}$ & $53 \mathrm{abc}$ & $46 \mathrm{~cd}$ & $34 \mathrm{e}$ & $44 \mathrm{c}$ \\
\hline $\mathrm{R}_{6}$ & $113 \mathrm{c}$ & $126 \mathrm{bc}$ & $119 \mathrm{c}$ & $119 \mathrm{~b}$ & $44 \mathrm{~d}$ & $54 \mathrm{abc}$ & $49 \mathrm{bcd}$ & $49 \mathrm{~b}$ \\
\hline $\mathrm{R}_{7}$ & $167 \mathrm{a}$ & $134 \mathrm{bc}$ & $131 \mathrm{bc}$ & $144 \mathrm{a}$ & $61 \mathrm{a}$ & $52 \mathrm{a}-\mathrm{d}$ & $56 \mathrm{ab}$ & $56 a$ \\
\hline $\mathrm{R}_{8}$ & $123 c$ & $150 \mathrm{ab}$ & $127 \mathrm{bc}$ & $133 \mathrm{a}$ & $47 \mathrm{bcd}$ & $60 \mathrm{a}$ & $52 \mathrm{a}-\mathrm{d}$ & $53 \mathrm{ab}$ \\
\hline FM & $129 \mathrm{bc}$ & $133 \mathrm{bc}$ & $131 \mathrm{bc}$ & $131 \mathrm{ab}$ & $54 \mathrm{abc}$ & $54 \mathrm{abc}$ & $54 \mathrm{abc}$ & $54 \mathrm{a}$ \\
\hline \multirow[t]{2}{*}{ Mean } & 132 & 133 & 124 & & 52 & 53 & 49 & \\
\hline & \multicolumn{8}{|c|}{ Seed weight per plant (g) } \\
\hline $\mathrm{R}_{5}$ & $15.5 \mathrm{e}$ & $17.7 \mathrm{de}$ & $17.5 \mathrm{de}$ & $16.9 \mathrm{~d}$ & $7.8 \mathrm{gh}$ & $5.7 \mathrm{~h}$ & $5.9 \mathrm{~h}$ & $6.5 \mathrm{c}$ \\
\hline $\mathrm{R}_{6}$ & $29.5 \mathrm{c}$ & $25.0 \mathrm{~cd}$ & $28.0 \mathrm{c}$ & $27.5 \mathrm{c}$ & $17.3 \mathrm{ab}$ & $10.0 \mathrm{fg}$ & $10.6 \mathrm{efg}$ & $12.6 \mathrm{~b}$ \\
\hline $\mathrm{R}_{7}$ & $65.6 \mathrm{a}$ & $45.2 \mathrm{~b}$ & $59.0 \mathrm{a}$ & $56.5 \mathrm{a}$ & $18.8 \mathrm{a}$ & $14.9 \mathrm{bcd}$ & $14.1 \mathrm{bcd}$ & $15.9 \mathrm{a}$ \\
\hline $\mathrm{R}_{8}$ & $47.1 \mathrm{~b}$ & $62.2 \mathrm{a}$ & $47.0 \mathrm{~b}$ & $52.0 \mathrm{a}$ & $12.4 \mathrm{def}$ & $16.4 \mathrm{abc}$ & $12.2 \mathrm{def}$ & $13.6 \mathrm{~b}$ \\
\hline FM & $40.9 \mathrm{~b}$ & $47.0 \mathrm{~b}$ & $31.5 \mathrm{c}$ & $39.8 \mathrm{~b}$ & $13.8 \mathrm{cde}$ & $13.8 \mathrm{cde}$ & $13.8 \mathrm{cde}$ & $13.8 \mathrm{~b}$ \\
\hline Mean & 39.7 & 39.4 & 36.5 & & $14.1 \mathrm{a}$ & $12.2 \mathrm{~b}$ & $11.3 \mathrm{~b}$ & \\
\hline
\end{tabular}

*: Means followed by same letter(s) are not significant at $\mathrm{p}<0.05$. FM: Full maturation

No significant changes were observed in plant height of soybean as affected by desiccants and application times (Table 2). Plant height was measured between $95 \mathrm{~cm}$ and $115 \mathrm{~cm}$ in the first year and it was recorded as $96-119 \mathrm{~cm}$ in the second year. It means that the plants stop growing or little growth occurs after $R_{5}$ stage. A significant two-way interaction of desiccant $\times$ application' time for first pod height, pod number and seed weight per plant was found. In both years, uprooted and glyphosate applied plants in $\mathrm{R}_{7}$ gave the highest pod height, while the plants treated with diquat showed in $\mathrm{R}_{8}$. Similarly, the highest pod number and seed weight per plant were detected in $\mathrm{R}_{7}$ stage of the plants uprooted and treated with glyphosate. Pereira et al. (2015) determined no significant differences between glyphosate and diquat for pod number plant ${ }^{-1}$ and seed weight in spite of higher pod number plant ${ }^{-1}$ in earlier application of glyphosate. However, diquat produced higher pod number and seed weight in soybean plant in $\mathrm{R}_{8}$ stage. It means that the activity of diquat was faster than glyphosate and it effectively desiccated soybean plants when it was applied. Our observation showed that it dried firstly the leaves during 3 days after spraying, but main and branch stems took longer time compared to glyphosate to desiccate. This finding was supported by Whigham and Stoller (1979), they stated that the most effective desiccant for hasten harvest date of soybean was paraquat and it decreased seed weight and yield when applied before $\mathrm{R}_{7}$ stage. 
Ergin N and Kaya MD (2020). Not Bot Horti Agrobo 48(3):1465-1472

Table 3. Changes in thousand seed weight, seed yield and oil ratio of soybean affected by desiccants and application times

\begin{tabular}{|c|c|c|c|c|c|c|c|c|}
\hline & \multicolumn{4}{|c|}{$1^{\text {st }}$ year } & \multicolumn{4}{|c|}{$2^{\text {nd }}$ year } \\
\hline Stage & Uprooted & Diquat & Glyphos. & Mean & Uprooted & Diquat & Glyphos. & Mean \\
\hline & \multicolumn{8}{|c|}{ Thousand seed weight (g) } \\
\hline $\mathrm{R}_{5}$ & $95 \mathrm{~d}$ & $108 \mathrm{de}$ & $126 \mathrm{c}$ & $110 \mathrm{c}$ & $55 \mathrm{e}$ & $72 \mathrm{~d}$ & $74 \mathrm{~d}^{*}$ & $67 \mathrm{c}$ \\
\hline $\mathrm{R}_{6}$ & $119 c$ & $126 \mathrm{c}$ & $146 \mathrm{~b}$ & $130 \mathrm{~b}$ & $100 \mathrm{c}$ & $106 \mathrm{bc}$ & $107 \mathrm{abc}$ & $104 \mathrm{~b}$ \\
\hline $\mathrm{R}_{7}$ & $154 \mathrm{ab}$ & $156 \mathrm{ab}$ & $168 \mathrm{ab}$ & $159 a$ & $115 \mathrm{ab}$ & $107 \mathrm{ab}$ & $115 \mathrm{ab}$ & $116 \mathrm{a}$ \\
\hline $\mathrm{R}_{8}$ & $157 \mathrm{ab}$ & $168 \mathrm{ab}$ & $161 \mathrm{ab}$ & $162 \mathrm{a}$ & $113 \mathrm{ab}$ & $119 \mathrm{a}$ & $108 \mathrm{abc}$ & $113 \mathrm{a}$ \\
\hline FM & $172 \mathrm{a}$ & $149 \mathrm{ab}$ & $148 \mathrm{~b}$ & $156 \mathrm{a}$ & $118 \mathrm{a}$ & $118 \mathrm{a}$ & $118 \mathrm{a}$ & $118 \mathrm{a}$ \\
\hline \multirow[t]{2}{*}{ Mean } & 140 & 142 & 150 & & 100 & 104 & 104 & \\
\hline & \multicolumn{8}{|c|}{ Seed yield $\left(\mathrm{kg} \mathrm{ha}^{-1}\right)$} \\
\hline $\mathrm{R}_{5}$ & $883 \mathrm{f}$ & $1,154 \mathrm{f}$ & $2,055 \mathrm{de}$ & $1,364 \mathrm{c}$ & $773 \mathrm{~g}$ & $1,010 \mathrm{~g}$ & $1,508 \mathrm{f}$ & $1,097 \mathrm{~d}$ \\
\hline $\mathrm{R}_{6}$ & $1,739 \mathrm{de}$ & $1,643 \mathrm{e}$ & $2,216 \mathrm{~cd}$ & $1,866 \mathrm{~b}$ & $1,987 \mathrm{de}$ & $2,126 \mathrm{de}$ & $2,292 \mathrm{~cd}$ & $2,135 \mathrm{c}$ \\
\hline $\mathrm{R}_{7}$ & $3,001 \mathrm{ab}$ & $2,659 \mathrm{bc}$ & $3,027 \mathrm{ab}$ & $2,896 \mathrm{a}$ & $1,871 \mathrm{e}$ & $2,565 \mathrm{bc}$ & $2,784 \mathrm{ab}$ & $2,407 \mathrm{~b}$ \\
\hline $\mathrm{R}_{8}$ & $3,081 \mathrm{ab}$ & $2,766 \mathrm{ab}$ & $3,278 \mathrm{a}$ & $3,042 \mathrm{a}$ & $2,940 \mathrm{a}$ & $2,640 \mathrm{abc}$ & $2,507 \mathrm{bc}$ & $2,696 \mathrm{a}$ \\
\hline FM & $3,175 \mathrm{ab}$ & $2,984 \mathrm{ab}$ & $2,948 \mathrm{ab}$ & $3,036 \mathrm{a}$ & $2,771 \mathrm{ab}$ & $2,821 \mathrm{ab}$ & $2,821 \mathrm{ab}$ & $2,804 \mathrm{a}$ \\
\hline \multirow[t]{2}{*}{ Mean } & 2,376 & 2,241 & 2,705 & & $2,068 \mathrm{~b}$ & $2,232 \mathrm{ab}$ & $2,382 \mathrm{a}$ & \\
\hline & \multicolumn{8}{|c|}{ Oil ratio (\%) } \\
\hline $\mathrm{R}_{5}$ & $18.8 \mathrm{~d}$ & $18.9 \mathrm{~d}$ & $20.1 \mathrm{c}$ & $19.2 \mathrm{~b}$ & $19.1 \mathrm{~cd}$ & $16.6 \mathrm{~d}$ & $20.2 \mathrm{bc}$ & $18.6 \mathrm{c}$ \\
\hline $\mathrm{R}_{6}$ & $20.4 \mathrm{bc}$ & $21.2 \mathrm{a}$ & $20.2 \mathrm{bc}$ & $20.6 \mathrm{a}$ & $21.9 \mathrm{abc}$ & $22.6 \mathrm{ab}$ & $20.1 \mathrm{bc}$ & $21.6 \mathrm{a}$ \\
\hline $\mathrm{R}_{7}$ & $20.6 \mathrm{abc}$ & $20.7 \mathrm{abc}$ & $20.4 \mathrm{bc}$ & $20.6 \mathrm{a}$ & $20.7 \mathrm{abc}$ & $23.1 \mathrm{a}$ & $19.9 \mathrm{bc}$ & $21.2 \mathrm{ab}$ \\
\hline $\mathrm{R}_{8}$ & $20.7 \mathrm{abc}$ & $20.5 \mathrm{abc}$ & $20.2 \mathrm{bc}$ & $20.5 \mathrm{a}$ & $19.0 \mathrm{~cd}$ & $21.4 \mathrm{abc}$ & $19.2 \mathrm{~cd}$ & $19.9 \mathrm{bc}$ \\
\hline FM & $20.5 \mathrm{abc}$ & $20.9 \mathrm{ab}$ & $20.4 \mathrm{bc}$ & $20.6 \mathrm{a}$ & $19.8 \mathrm{bc}$ & $19.8 \mathrm{bc}$ & $19.8 \mathrm{bc}$ & $19.8 \mathrm{bc}$ \\
\hline Mean & 20.2 & 20.4 & 20.3 & & $20.1 \mathrm{ab}$ & $20.7 \mathrm{a}$ & $19.8 \mathrm{~b}$ & \\
\hline
\end{tabular}

A thousand seed weight of soybean was considerably influenced by desiccants and application times in both years (Table 3). It was the lowest in the plants uprooted or treated with diquat or glyphosate in $R_{5}$ and $R_{6}$ stages. Increased soybean growth led to increasing a thousand seed weight but it was changed by desiccants. Reproductive stage of $R_{7}$ and later stages produced heavier seed weight $(168 \mathrm{~g})$ at application of glyphosate, and diquat at $\mathrm{R}_{8}$ with $168 \mathrm{~g}$. In second year, similar findings were recorded as delayed desiccant application time resulted in increasing seed weight. Toledo et al. (2014), Pereira et al. (2015), Finoto et al. (2017) and Rosado et al. (2019) supported the finding that seed weight improved when desiccant application was performed in later growth stages of $R_{6}$, but significant differences among desiccants. Significant changes in seed yield of soybean were determined according to desiccants and application times. In both years, $R_{5}$ and $R_{6}$ gave lower seed yield whatever desiccants were. Bennett and Shaw (2000) observed that early desiccant applications ( $R_{5}$ and $R_{6}$ ) reduced the seed yield in soybean. Both diquat and glyphosate applied at $R_{7}$ and $R_{8}$ produced the seed yield as much as full maturity. Except for full maturity, the highest seed yield was obtained from glyphosate treatment at $R_{8}$ with $3,278 \mathrm{~kg} \mathrm{ha}^{-1}$ in the first year and $2,784 \mathrm{~kg} \mathrm{ha}^{-1}$ in the second year. It was determined that the critical growth stage for desiccant spraying was at $\mathrm{R}_{7}$ because the desiccant applications in earlier stages caused a drastic reduction in seed yield. The results are in line with the findings of Zagonel (2005), Pereira et al. (2015), Finoto et al. (2017) and Araújo et al. (2018) who found that seed yield was promoted by delayed harvest time and adverse effects of desiccants on the soybean yield were identified. Rosado et al. (2019) stated that significant reduction in seed yield of soybean with paraquat application on $\mathrm{R}_{8}$, while Guimarães et al. (2012) determined that glyphosate had higher seed yield compared to ammonium glyphosinate and paraquat. Soltani et al. (2013) reported that no reduction in dry edible bean yields when desiccants (glyphosate and saflufenacil) were applied at full maturity. Furthermore, Ratnayake and Shaw (1992) stated that the adverse effects of herbicides were observed on seed yield, germination or seedling development of soybean when were applied at $\mathrm{R}_{8}$. Rahman et al. (2004) and Finoto et al. (2017) reported that early desiccation resulted in a 
dramatic decline in seed germination, seedling growth and seed vigour of soybean. If desiccant application times were retarded, seed yield of soybean reduced. In the study of Cerkauskas et al. (1982), seed yield was severely affected when paraquat was applied before full maturity. Likewise, reduction in seed yield and quality were observed when glyphosate was applied 3 to 4 wk before harvest (Azlin and McWhorter, 1981). Our results showed that oil content was remarkably changed by desiccants and application times and the lowest oil content was apparently obtained in $\mathrm{R}_{5}$ stage exposed to both diquat and glyphosate in both years. Diquat application at $\mathrm{R}_{6}$ in first and $\mathrm{R}_{7}$ in second year resulted in the highest oil content in soybean. Our results are supported by Finoto et al. (2017), who reported that early harvest clearly declined oil content of soybeans treated with diquat.

Desiccants allowed for accelerating of harvest time by 19-25 days when they were treated in $R_{5}$ and $R_{6}$ however, these stages created an unacceptable yield reduction (Table 4). On the other hand, in $\mathrm{R}_{7}$ stage their application resulted in earliness between 9 and 16 days depending on the number of days without precipitation. In addition, glyphosate gave longer harvest time from spraying than diquat to desiccate the plants during the experimental years. Our results are in line with the findings of Pereira et al. (2015) and Araújo et al. (2018).

Table 4. Harvest dates of soybean subjected to the desiccants and application times in 2016 and 2018 years

\begin{tabular}{|c|c|c|c|c|c|c|}
\hline \multirow{2}{*}{$\begin{array}{l}\text { Applic. } \\
\text { stage }\end{array}$} & \multicolumn{3}{|c|}{$1^{\text {st }}$ year } & \multicolumn{3}{|c|}{$2^{\text {nd }}$ year } \\
\hline & Uprooted & Diquat & Glyphos. & Uprooted & Diquat & Glyphos. \\
\hline $\mathrm{R}_{5}$ & 2 September & 20 September & 1 October & 19 August & 1 September & 5 September \\
\hline $\mathrm{R}_{6}$ & 11 September & 20 September & 6 October & 02 September & 11 September & 16 September \\
\hline $\mathrm{R}_{7}$ & 29 September & 10 October & 13 October & 16 September & 21 September & 24 September \\
\hline $\mathrm{R}_{8}$ & 13 October & 20 October & 20 October & 25 September & 30 September & 30 September \\
\hline $\begin{array}{c}\text { Full } \\
\text { maturity }\end{array}$ & \multicolumn{3}{|c|}{25 October } & \multicolumn{3}{|c|}{5 October } \\
\hline
\end{tabular}

\section{Conclusions}

In conclusion, desiccants may successfully be used as harvest aid chemicals for earliness and leaf defoliation in soybean, but timing is essential to produce enough seed yield and quality. In the study, it was determined that $\mathrm{R}_{7}$ stage of soybean was the crucial for high yielding soybean production without quality loss. The application of desiccants led to earliness between 7 and 10 days compared to untreated control although the effectiveness of desiccants was very different from each other and diquat dried the soybean plants more rapidly than glyphosate. For this reason, diquat should be preferred if soybean plant was in later than $\mathrm{R}_{7}$ stage. It was concluded that glyphosate application at growth stage of $\mathrm{R}_{7}$ should be advised for shortening harvest date of soybean.

\section{Authors' Contributions}

Both authors read and approved the final manuscript.

\section{Acknowledgements}

This research was extracted from Ph.D. Thesis of first author, N.E., Department of Field Crops, Graduate School of Natural and Applied Sciences, Eskişehir Osmangazi University, Turkey. This research received no specific grant from any funding agency in the public, commercial, or not-for-profit sectors. 
Ergin N and Kaya MD (2020). Not Bot Horti Agrobo 48(3):1465-1472

\section{Conflict of Interests}

The authors declare that there are no conflicts of interest related to this article.

\section{References}

Anonymous (2019). Soybean breeding. Retrieved 2019 October 20 from https://arastirma.tarimorman.gov.tr/cukurovataem/Belgeler/Yeti\%C5\%9Ftiricilik/soya-yetistiriciligi_1.pdf

Araújo DL, Lazzari MP, Dutra R, Lajús CR, Klein C, Cericato A, Junges M (2018). Influência dos períodos de dessecação da soja na germinação e componentes de rendimento [Influence of soybean desiccation periods on its germination potential and yield components]. Revista Brasileira de Ciências Agrárias 13(4):5584. https://doi.org/10.5039/agraria.v13i4a5584

Azlin WR, McWhorter CG (1981). Preharvest effects of applying glyphosate to soybeans (Glycine max). Weed Science 29(1):123-127. https://doi.org/10.1017/s0043174500025972

Bennett AC, Shaw DR (2000). Effect of preharvest desiccants on group IV Glycine max seed viability. Weed Science 48(4):426-430. https://doi.org/10.1614/0043-1745(2000)048[0426:EOPDOG]2.0.CO;2

Boudreaux JM, Griffin JL (2011). Application timing of harvest aid herbicides affects soybean harvest and yield. Weed technology 25(1):38-43. https://doi.org/10.1614/WT-D-10-00045.1

Cerkauskas RF, Dhingra OD, Sinclair JB, Foor SR (1982). Effect of three desiccant herbicides on soybean (Glycine max) seed quality. Weed Science 30(5):484-490. https://doi.org/10.1017/s0043174500041023

Finoto EL, Sediyama T, Albuquerque J, Soares MBB, Galli JA, Cordeiro Junior PS, Menezes PHS (2017). Anticipation and harvest delay in oil and protein contents of soybean seeds, grow crops Valiosa RR. Scientia Agropecuaria 8(2):99-107. https://doi.org/10.17268/sci.agropecu.2017.02.02

Guimarães VF, Hollmann MJ, Fioreze SL, Echer MM, Rodrigues-Costa ACP, Andreotti M (2012). Produtividade e qualidade de sementes de soja em função de estádios de dessecação e herbicidas [Productivity and quality of soybean seeds in function of desiccation stages and herbicides]. Planta Daninha 30(3):567-573. https://doi.org/10.1590/s0100-83582012000300012

Kolsarıcı Ö, Kaya MD, Göksoy AT, Arıoğlu H, Kulan EG, Day S (2015). Yağlı tohum üretiminde yeni arayışlar [New approaches for oil seed production]. Türkiye VII. Ziraat Mühendisliği Teknik Kongresi Bildiriler Kitabı-1 pp 401-425.

Kulan EG, Ergin N, Demir İ, Kaya MD (2017). Eskişehir koşullarında bazı soya (Glycine max L.) çeşitlerinin önemli tarımsal özellikleri ve adaptasyonunun belirlenmesi [he determination of agronomic characteristics and adaptation of some soybean (Glycine max L.) cultivars in Eskişehir conditions]. Uludağ Üniversitesi Ziraat Fakültesi Dergisi 31(1):127-135. http://hdl.handle.net/11452/5830

Pereira T, Coelho CMM, Souza CA, Mantovani A, Mathias V (2015). Dessecação química para antecipação de colheita em cultivares de soja [Chemical desiccation for early harvest in soybean cultivars]. Semina: Ciências Agrárias, Londrina 36(4):2383-2394. https://doi.org/10.1017/s0890037x00034837

Ratnayake S, Shaw DR (1992). Effects of harvest-aid herbicides on soybean (Glycine max) seed yield and quality. Weed Technology 6(2):339-344. https://doi.org/10.1017/s0890037x00034837

Rahman MM, Hampton JG, Hill MJ (2004). Soybean seed quality in response to time of desiccant application. Seed Science and Technology 32:219-223. https://doi.org/10.15258/sst.2004.32.1.23

Rosado CB, Pereira GAM, Capobiango NP, Moreira RPL, Freitas FCL, Teixeira MFF, Da Silva AA (2019). Physiological quality of bean seeds after application of desiccant herbicides. Ciência Rural 49(9), e20180228. https://doi.org/10.1590/0103-8478cr20180228

Soltani N, Blackshaw RE, Gulden RH, Gillard CL, Shropshire C, Sikkema PH (2013). Desiccation in dry edible beans with various herbicides. Canadian Journal of Plant Science 93(5):871-877. https://doi.org/10.4141/cjps2013061

Toledo MZ, Dubay AC, Miggliavacca RA, Felix JC (2014). Soybean seed pre-harvest desiccation and physiological quality from an indeterminate growth cultivar. Seed Technology pp 29-40.

Torunlar H, Nazlıcan AN (2018). Türkiye'de ana ürün olarak yetiştirilecek soyanın (Glycine max L. merrill) çok kriterli karar verme yöntemiyle arazi uygunluk analizinin yapılması [Land suitability analysis of main crop soybean 
(Glycine max L. Merrill.) cultivation in Turkey through the multi criteria decision making method]. Anadolu Journal of Agricultural Sciences 33(3):270-281. https://doi.org/10.7161/omuanajas.401431

Whigham DK, Stoller EW (1979). Soybean desiccation by paraquat, glyphosate, and ametryn to accelerate harvest. Agronomy Journal 71(4):630-633. https://doi.org/10.2134/agronj1979.00021962007100040027x

Zagonel $\mathrm{J}$ (2005). Herbicide application timing in preharvest desiccation of soybean cultivars with different growth habits. Journal of Environmental Science and Health-Part B 40(1):13-20. https://doi.org/10.1081/pfc-200034198
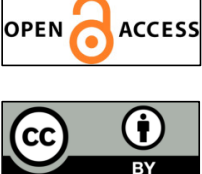

The journal offers free, immediate, and unrestricted access to peer-reviewed research and scholarly work. Users are allowed to read, download, copy, distribute, print, search, or link to the full texts of the articles, or use them for any other lawful purpose, without asking prior permission from the publisher or the author.

License - Articles published in Notulae Botanicae Horti Agrobotanici Cluj-Napoca are Open-Access, distributed under the terms and conditions of the Creative Commons Attribution (CC BY 4.0) License.

(c) Articles by the authors; UASVM, Cluj-Napoca, Romania. The journal allows the author(s) to hold the copyright/to retain publishing rights without restriction. 